\title{
Pengaruh Laba per Saham, Rasio Hutang dan Pengembalian atas Aset (ROA) terhadap Harga Saham
}

(Studi Kasus pada Perusahaan Pertambangan)

\author{
Jocelyn Govia \\ Universitas Prima Indonesia \\ jocelyngovia97@gmail.com \\ Enggolit Ramayanti \\ Universitas Prima Indonesia \\ ramayantia9@gmail.com
}

\author{
Venita Ozty Susan Dayani \\ Universitas Prima Indonesia \\ venitaoztysusan@gmail.com \\ Michael Tanoto \\ Universitas Prima Indonesia \\ michaeltanoto1997@gmail.com \\ Cynthia \\ Universitas Prima Indonesia \\ cynthiayanggg@gmail.com
}

\author{
Mohd.Nawi Purba \\ Universitas Prima Indonesia \\ nawi_purba@yahoo.com \\ Sauh HweeTeng \\ Universitas Prima Indonesia \\ tengsauhhwee@unprimdn.ac.id
}

\begin{abstract}
The purpose of this research is to examine the influence of earning per share, debt to equity ratio, and return on assets (ROA) to stock price. This research was conducted on mining companies listed in Indonesia Stock Exchange period 2012-2017. The analysis method used is multiple linear regression analysis, $F$ test and $T$ test. The analysis result of this research shows that stock price is influenced simultaneously by earning per share, debt to equity ratio, and return on assets (ROA). Meanwhile, the partial analysis shows that earning per share influences significantly on stock price, debt to equity ratio influences but insignificantly on stock price, and return on assets (ROA) doesn't influence but is significant on stock price.

Keywords : earning per share, debt to equity ratio, return on assets, stock price
\end{abstract}

\begin{abstract}
ABSTRAK
Penelitian ini bertujuan untuk mengetahui pengaruh laba per saham, rasio hutang dan pengembalian atas aset terhadap harga saham. Penelitian ini dilakukan pada perusahaan pertambangan yang terdaftar di BEI tahun 2012-2017. Metode analisis yang digunakan adalah regresi linerar berganda, uji F dan uji T. Hasil analisis dari penelitian ini adalah laba per saham, rasio hutang, dan pengembalian atas aset (ROA) berpengaruh secara simultan terhadap harga saham. Sedangkan analisis secara parsial menunjukkan laba per saham berpengaruh signifikan terhadap harga saham, dan rasio hutang berpengaruh dan tidak signifikan terhadap harga saham, pengembalian atas aset (ROA) tidak berpengaruh dan signifikan terhadap harga saham.
\end{abstract}

Kata kunci : laba per saham, rasio hutang, pengembalian atas aset, harga saham Pendahuluan

\section{I.1. Latar Belakang}

Pasar modal merupakan salah satu penggerak utama perekonomian dunia termasuk Indonesia sendiri, dengan melalui pasar modal perusahaan dapat memperoleh dana untuk kegiatan perekonimiannya. Hal ini terbukti dengan semakin meningkatnya jumlah perusahaan yang terdaftar di Bursa Efek Indonesia (BEI) yang menjual saham kepada para investor.

Pertambangan adalah suatu kegiatan pengambilan endapan bahan galian berharga dan 
bernilai ekonomis dari dalam kulit bumi, baik secara mekanis maupun manual, pada permukaan bumi, di bawah permukaan bumi dan di bawah permukaan air. Hasil kegiatan ini antara lain, minyak dan gas bumi, batubara, pasir besi, bijih timah, bijih nikel, bijih bauksit, bijih tembaga, bijih emas, perak dan bijih mangan (Sumber: Katalog BPS:Data Strategis BPS). Perusahaan pertambangan memberikan prospek yang terbaik di masa mendatang. Industri pengolahan berbasis sumber daya alam (pertambangan, batu bara serta minyak dan migas), diperkirakan berpeluang menjadi motor penggerak dan fokus perekonomian Indonesia di masa yang akan mendatang. Hal ini dibuktikan dengan salah satu subsektornya yaitu pertambangan batu-batuan menjadi sektor ekonomi yang paling dominan di Indonesia selama 2013-2014.

Para investor tertarik untuk menanamkan investasinya di perusahaan pertambangan karena berkeyakinan bahwa mereka dapat memperoleh keuntungan yang besar karena perusahaan pertambangan membagikan laba yang diperolehnya sesuai dengan tinggi rendahnya laba per saham perusahaan pertambangan.

Harga saham adalah harga yang terbentuk di pasar modal dengan nilai yang ditetapkan oleh emitmen untuk menilai setiap lembar saham yang dikeluarkan. Harga saham sebagai nilai perubahan harga dalam perdagangan dan menghasilkan keuntungan yang lebih tinggi, sehingga akan memungkinkan perusahaan untuk menyisihkan bagian keuntungan itu sebagai dividen dengan jumlah yang tinggi.

Laba per saham adalah rasio yang mengukur berapa besar laba bersih yang dihasilkan oleh perusahaan untuk setiap lembar saham yang beredar yang diperoleh pemegang saham dengan membagi laba bersih perusahaan dengan jumlah saham yang beredar.

Rasio hutang pada perusahaan merupakan pengorbanan manfaat ekonomi masa mendatang yang mungkin timbul karena kewajiban suatu entitas yang menggunakan debt-to-equity ratio juga dapat memberikan gambaran tentang kemampuan perusahaan dalam mengeloladan melunasi kewajibannya serta struktur yang dimiliki oleh suatu perusahaan.

Berkurangnya investasi para investor diakibatkan tingkat pendapatan yang menurun secara tidak sengaja menurunkan laba bersih perusahaan pertambangan. Padahal investasi dari para investor di perusahaan pertambangan ini penting dalam meningkatkan return on asset perusahaan. Untuk meningkatkan pengembalian atas aset yang tinggi tentu harga saham juga ikut meningkat. Perusahaan yang memiliki return on asset yang tinggi maka harga saham perusahaan juga akan meningkat. Sedangkan perusahaan yang memiliki return on asset yang rendah maka harga saham perusahaan juga akan menurun.

\section{Tabel 1.1}

Perkembangan Laba Per Saham, Total Hutang,Laba Bersih dan Harga Saham Perusahaan periode 2012-2017

\begin{tabular}{|c|c|c|c|c|c|c|}
\hline $\begin{array}{c}\text { N } \\
\mathbf{o}\end{array}$ & $\begin{array}{c}\text { Kode } \\
\text { Emiten }\end{array}$ & Tahun & $\begin{array}{c}\text { Laba } \\
\text { Per } \\
\text { Saham }\end{array}$ & $\begin{array}{c}\text { Total Hu- } \\
\text { tang } \\
\text { (Jutaan) }\end{array}$ & $\begin{array}{c}\text { Laba Ber- } \\
\text { sih } \\
\text { (Jutaan) }\end{array}$ & $\begin{array}{c}\text { Harga } \\
\text { Saham }\end{array}$ \\
\hline 1 & ADRO & 2012 & 116,52 & 35.751 & 3.706 & 1.590 \\
\hline & & 2013 & 88,12 & 43.134 & 2.794 & 1.090 \\
\hline & & 2014 & 69,29 & 39.254 & 2.283 & 1.040 \\
\hline & & 2015 & 65,80 & 35.944 & 2.083 & 515 \\
\hline & & 2016 & 140,54 & 36.765 & 4.577 & 1.695 \\
\hline & & 2017 & 204,71 & 36.884 & 7.267 & 1.860 \\
\hline 2 & KKGI & 2012 & 232,08 & 294.960 & 228.113 & 2.475 \\
\hline & & 2013 & 219,40 & 399.031 & 210.142 & 2.050 \\
\hline & & 2014 & 99,52 & 340.536 & 99.548 & 1.005 \\
\hline & & 2015 & 82,77 & 300.460 & 78.248 & 420 \\
\hline & & 2016 & 134,36 & 192.121 & 127.277 & 1.500 \\
\hline & & 2017 & 40,64 & 222.643 & 182.084 & 324 \\
\hline 3 & TINS & 2012 & 86 & 1.542 .807 & 431.588 & 1.540 \\
\hline & & 2013 & 109 & 2.991 .184 & 544.401 & 1.600 \\
\hline & & 2014 & 91 & 4.144 .235 & 637.954 & 1.230 \\
\hline & & 2015 & 14 & 3.908 .615 & 101.561 & 505 \\
\hline & & 2016 & 38 & 3.894 .946 & 283.049 & 1.075 \\
\hline & & 2017 & 68 & 5.814 .816 & 508.914 & 775 \\
\hline
\end{tabular}

Dari Tabel I.1 di atas menunjukkan bahwa total hutang ADRO di tahun 2013 sebesar Rp 43.134.000.000 atau 20,64\% mengalami peningkatan dibandingkan tahun 2012 dengan harga saham di tahun 2013 sebesar Rp 1.090 atau $31,45 \%$ mengalami penurunan dibandingkan tahun 2012.

KKGI yang memiliki total hutang di tahun 2013 sebesar Rp 399.031.000.000 atau $35,28 \%$ mengalami peningkatan dibandingkan tahun 2012 dengan harga saham di tahun 2013 sebesar Rp 2.050 atau 17,17\% mengalami penurunan dibandingkan tahun 2012. 
TINS yang memiliki laba per saham di tahun 2017 sebesar Rp 68 atau 78,95\% mengalami peningkatan dibandingkan tahun 2016 sedangkan laba bersih di tahun 2017 sebesar Rp 508.914.000.000 atau 79,78\% mengalami peningkatan dibandingkan tahun 2016 dengan harga saham di tahun 2017 sebesar Rp 775 atau 27,9\% mengalami penurunan dibandingkan tahun 2016.

Penelitian ini bertujuan untuk mengetahui signifikansi Pengaruh Laba Per Saham, Rasio Hutang, Pengembalian atas Aset (ROA) Terhadap Harga Saham.

\section{Kajian Pustaka}

\subsection{Pengertian Laba per Saham}

Menurut Murhadi (2013:64-65) Earn-

ing Per Share merupakan pendapatan per lembar saham yang dapat dilihat pada laporan laba rugi. EPS mencerminkan pendapatan tiap lembar saham yang diperoleh pemegang saham, bila semua pendapatan tersebut dibagikandalam bentuk dividen.

\subsection{Pengertian Rasio Hutang}

Menurut Hery (2016:78) Rasio Hutang terhadap modal meripakan rasio yang digunakan untuk mengukur besarnya proporsi utang terhadap modal. Rasio ini dihitung sebagai hasil bagi antara total utang dengan modal.

\subsection{Pengertian Pengembalian Aset (ROA)}

Menurut Dwi Prastowo (2015:81) return on assetsmengukur kemampuan perusahaan dalam memanfaatkan aktivanya untuk memperoleh laba. Rasio ini mengukur tingkat pengembalian investasi yang telah dilakukan oleh perusahaan dengan menggunakan seluruh dana (aktiva) yang dimilikinya.

\subsection{Pengertian Harga Saham}

Menurut Widoatmodjo (2012:56) mengartikan, harga nominal saham merupakan nilai yang ditetapkan oleh emiten, untuk menilai setiap lembar saham yang dikeluarkannya.
Besarnya harga nominal ini sebenarnya bergantung pada keinginan emiten. Emiten bebas menetapkan harga per lembar sahamnya.

\section{Metode Penelitian}

Jenis penelitian yang digunakan pada penelitian ini adalah penelitian deskriptif kuantitatif karena penelitian ini dilakukan untuk mengetahui nilai masing-masing variabel. Pendekatan penelitian pada penelitian ini adalah pendekatan metode kuantitaif karena data-data yang dipakai berbentuk angka. Sumber utama penelitian ini adalah dengan cara mengakses data yang ada pada situs BEI, yaitu www.idx.co.id. Data yang dipakai berupa laporan keuangan perusahaan pertambangan yang terdapat dalam situs tersebut.

Penelitian ini memilih perusahaan dengan menggunakan teknik purposive sampling, yaitu metode dengan memilih sampel berdasarkan kriteria tertentu. Adapun kriteria yang diambil, yaitu : (1) perusahaan pertambangan yang terdaftar dalam BEI periode 2012-2017, (2) perusahaan pertambangan yang menerbitkan laporan keuangan yang diaudit oleh auditor independen secara lengkap, (3) perusahaan pertambangan yang mendapatkan laba pada periode 2012-2017. Berdasarkan kriteria yang ditetapkan pada penelitian ini, jumlah sampel yang ditetapkan ada 9 perusahaan selama 6 tahun sehingga jumlah sampel penelitian ada 54 data perusahan.

Analisis data penelitian yang digunakan adalah uji regresi linier berganda dengan uji asumsi klasik yang terdiri dari uji normalitas, uji multikoloniaritas, uji heteroskedastisitas dan uji autokorelasi.

\subsection{Definisi Operasional Variabel Penelitian}

Variabel independen adalah Harga Saham. Menurut Martalena dan Malinda (2011:99), Indeks saham merupakan suatu indikator yang menunjukkan pergerakan harga saham. Menurut Widoatmodjo (2012:58), indikator harga saham adalah sebagai berikut :

Harga saham = Penutupan harga saham tahunan

Variabel dependen dalam penelitian ini adalah :

1. Laba per Saham 
Menurut Murhadi (2013:64), indikator untuk menghitung laba per saham adalah sebagai berikut :

$$
E P S=\frac{\text { Net Income }}{\text { Jumlah Saham Biasa }}
$$

\section{Rasio Hutang}

Menurut Prastowo (2015:79), indikator untuk menghitung rasio hutang adalah sebagai berikut:

$$
\text { Debt to Equity }=\frac{\text { Total Hutang }}{\text { Total Modal }}
$$

\section{Pengembalianatas aset (ROA)}

Menurut Murhadi (2013:64), indikator untuk menghitung pengembalian atas aset (ROA) adalah sebagai berikut :

$$
R O A=\frac{\text { Net Income }}{\text { Total Assets }}
$$

\subsection{Kerangka Konseptual}

Kerangka konseptual yang digunakan dalam penilitan Laba per Saham, Rasio Hutang, dan Pengembalian atas Aset (ROA) sebagai variabel independentdan variabel Harga Saham sebagai variabel dependent.

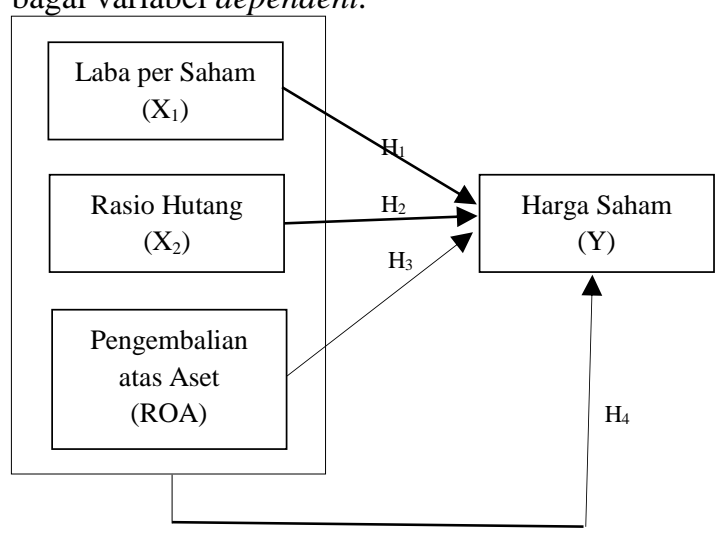

\section{Gambar 1. Kerangka Konseptual}

Sumber : Hasil Olahan Peneliti (2019)

Berdasarkan kerangka konseptual di atas, maka dapat disusun hipotesis penelitian sebagai berikut
$\mathrm{H}_{1} \quad$ Laba per saham berpengaruh secara parsial terhadap harga saham pada perusahaan pertambangan yang terdaftar di Bursa Efek Indonesia (BEI) Periode 2012-2017.

$\mathrm{H}_{2}$ Rasio hutang berpengaruh secara parsial terhadap harga saham pada perusahaan pertambangan yang tedaftar di Bursa Efek Indonesia (BEI)

$$
\text { Periode 2012-2017. }
$$

$\mathrm{H}_{3}$ Pengembalian atas aset (ROA) berpengaruh secara parsial ter hadap harga saham pada perusahaan pertambangan yang ter daftar di Bursa Efek Indonesia (BEI) Periode 2012-2017.

$\mathrm{H}_{4}$ Laba per saham,rasio hutang, dan pengembalian atass aset (ROA) berpengaruh secara simultan terhadap harga saham pada perusahaan pertambangan yang terdaftar diBursa Efek Indonesia (BEI)Periode 2012 2017.

\section{Hasil dan Pembahasan}

4.1. Statistik Deskriptif

Sampel pada penelitian ini adalah berjumlah 32 perusahaan dengan periode penelitian dari tahun 2012-2017, sehingga data penelitiannya $(\mathrm{N})$ yang diperoleh berjumlah 54 . Hasil pengolahan data dapat dilihat dari statistik deskriptif di bawah ini

Tabel 2. Statistik Deskriptif

\begin{tabular}{l|r|r|r|r|r}
\multicolumn{7}{c}{ Descriptive Statistics } \\
& N & Minimum & Maximum & Mean & Std. Deviation \\
\hline EPS & 54 & .23 & 3697.46 & 346.4278 & 695.69323 \\
\hline DER & 54 & .17 & 3.94 & 1.0544 & 1.01212 \\
\hline ROA & 54 & .00 & .29 & .0696 & .06904 \\
\hline HS & 54 & 56.00 & 41550.00 & 4358.7037 & 7844.08583 \\
\hline Valid N (listwise) & 54 & & & & \\
\hline
\end{tabular}

\subsection{Hasil Uji Asumsi Klasik Uji Normalitas}

Tabel 3. Uji Normalitas menggunakan Kolmogorov Smirnov 


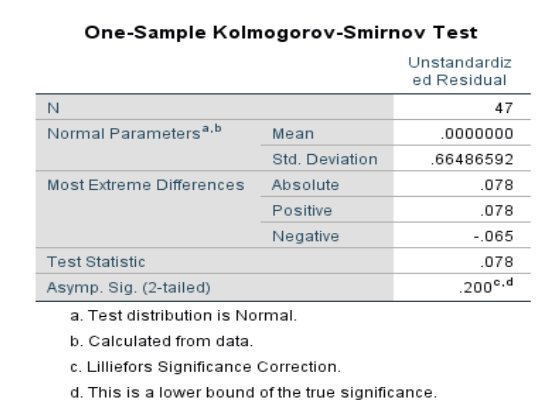

Sumber : Hasil Pengolahan Data, 2019

Pada Tabel. 3 menunjukkan bahwa hasil Uji Normalitas penelitian ini menggunakan Kolomogrov Smirnov menyatakan bahwa variabel laba per saham $\left(\mathrm{x}_{1}\right)$, rasio hutang $\left(\mathrm{x}_{2}\right)$, pengembalian atas aset $(\mathrm{ROA})\left(\mathrm{X}_{3}\right)$ dan harga saham (Y) sudah memenuhi syarat distribusi normal karena nilai sig 0,200 > 0,05 sehingga data tersebut normal.

\section{Uji Multikolinearitas}

Tabel 4. Uji Multikolinearitas

\begin{tabular}{lll|l}
\multicolumn{2}{c}{ Coefficients $^{\mathbf{a}}$} \\
$\begin{array}{l}\text { Model } \\
\text { Collinearity Statistics } \\
\text { Tolerance }\end{array}$ & VIF \\
\hline 1 & & & \\
\hline & (Constant) & & \\
\cline { 2 - 4 } & LN_EPS & .437 & 2.286 \\
\cline { 2 - 4 } & LN_DER & .800 & 1.250 \\
\cline { 2 - 4 } & LN_ROA & .381 & 2.627 \\
\hline
\end{tabular}

a. Dependent Variable: LN_HS

\section{Sumber : Hasil Pengolahan Data}

Pada Tabel.4 hasil uji multikolinearitas pada penelitian ini menunjukkan nilai tolerance variabel laba per saham $\left(\mathrm{x}_{1}\right)$, rasio hutang $\left(\mathrm{x}_{2}\right)$, pengembalian atas aset $(\mathrm{ROA})\left(\mathrm{X}_{3}\right)$ lebih besar dari 0,10 dapat disimpulkan bahwa tidak terjadi multikolinearitas. Nilai VIF yang diperoleh untuk variabel laba per saham $\left(\mathrm{x}_{1}\right)$, rasio hutang $\left(\mathrm{x}_{2}\right)$, pengembalian atas aset (ROA) $\left(\mathrm{X}_{3}\right)$ lebih kecil 10. Jadi dapat disimpulkan tidak terjadinyamultikolinearitas diantar variabel independen dalam model regresi tersebut.

\section{Uji Autokorelasi}

Tabel 5. Autokorelasi dengan Durbin Watson

\begin{tabular}{|c|c|c|c|c|c|}
\hline \multicolumn{6}{|c|}{ Model Summary ${ }^{b}$} \\
\hline Model & $\mathrm{R}$ & R Square & $\begin{array}{l}\text { Adjusted R } \\
\text { Square }\end{array}$ & $\begin{array}{l}\text { Std. Error of } \\
\text { the Estimate }\end{array}$ & $\begin{array}{l}\text { Durbin- } \\
\text { Watson }\end{array}$ \\
\hline 1 & $.904^{\mathrm{a}}$ & .818 & .805 & .68767 & 1.963 \\
\hline
\end{tabular}

Sumber : Hasil Pengolahan Data, 2019

Pada Tabel. 5 hasil uji Autokorelasi menggunakan Durbin Watson menunjukkan bahwa nilai Durbin Watson yang diperoleh adalah sebesar 1,963. Cara pengukuran uji autokorelasi adalah $\mathrm{du}<\mathrm{dw}<4-\mathrm{du}$. Nilai dl dan du dalam penelitian ini dengan menggunakan jumlah 3 variabel dan sampel penelitian sebanyak 47 maka nilai $\mathrm{dl}=1.3989$ dan nilai du $=1.6692$. Hasil pengukurannya adalah $\mathrm{du}<\mathrm{dw}<$ 4 - du maka $1.6692<1,963<(4-1.6692)$ sehingga $1.6692<1,963<2,3308$ sehingga disimpulkan tidak terjadi autokorelasi dalam penelitian ini.

\section{Uji Heteroskedastisitas}

\section{Tabel 6. Hasil Pengujian Heterokedastisitas dengan Uji Park}

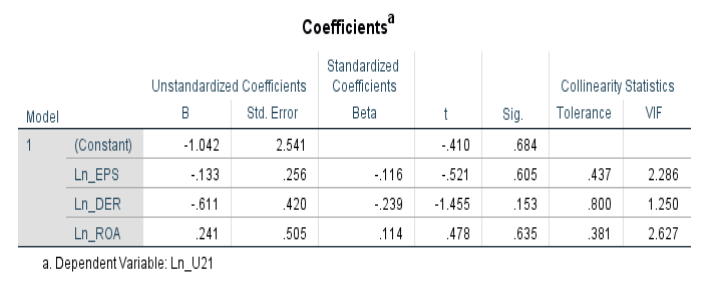

\section{Sumber : Hasil Pengolahan Data 2019}

Pada Tabel. 6 hasil pengujian heterokedastisitas pada model regresi diatas menunjukkan nilai signifikan variabel Laba per saham $\left(\mathrm{x}_{1}\right)$ danpengembalian atas aset (ROA) $\left(\mathrm{X}_{3}\right)$ di atas 0,05 disimpulkan tidak terjadi heteroskedastisitas.Rasio hutang $\left(\mathrm{x}_{2}\right)$ dengan nilai signifikan di bawah 0,05 disimpulkan terjadi heteroskedastisitas.

\subsection{Hasil analisis data penelitian Model penelitian}

Pengujian hipotesis yang digunakan dalam penelitian adalah menggunakan analisis regresi linier berganda. Model regresi yang digunakan adalah sebagai berikut:

Ln_HS $=2,560+0,799$ Ln_EPS $-0,733$

Ln_DER - 0,243 Ln_ROA 
Tabel 7. Model Penelitian

\begin{tabular}{|c|c|c|c|c|c|c|}
\hline \multirow[b]{3}{*}{ Model } & & \multicolumn{5}{|c|}{ Coefficients $^{a}$} \\
\hline & & \multicolumn{2}{|c|}{ Unstandardized Coefficients } & \multirow{2}{*}{$\begin{array}{c}\text { Standardized } \\
\text { Coefficients } \\
\text { Beta }\end{array}$} & \multirow[b]{2}{*}{$t$} & \multirow[b]{2}{*}{ Sig. } \\
\hline & & $B$ & Std. Error & & & \\
\hline \multirow[t]{4}{*}{1} & (Constant) & 2.560 & .911 & & 2.810 & .007 \\
\hline & LN_EPS & .799 & .092 & .858 & 8.715 & .000 \\
\hline & LN_DER & -.733 & .151 & -.354 & -4.870 & .000 \\
\hline & LN_ROA & -.243 & .181 & -.141 & -1.341 & .187 \\
\hline
\end{tabular}

Sumber : Hasil Pengolahan Data, Koefisien determinasi hipotesis

Koefisien determinasi digunakan untuk mengukur seberapa besar kemampuan pengaruh variabel bebas dapat menjelaskan variabel terikat. Semakin besar nilai koefisien determinasi, maka semakin baik kemampuan varian dan variabel bebas menerangkan variabel terikat. Berikut hasil koefisien determinasi hipotesis pada penelitian ini :

\section{Tabel 8. Koefisien Determinasi Hipotesis}

\begin{tabular}{|c|c|c|c|c|}
\hline \multirow[b]{2}{*}{ Model } & \multicolumn{4}{|c|}{ Model Summary } \\
\hline & $\mathrm{R}$ & R Square & $\begin{array}{l}\text { Adjusted R } \\
\text { Square }\end{array}$ & $\begin{array}{l}\text { Std. Error of } \\
\text { the Estimate }\end{array}$ \\
\hline 1 & $.904^{\mathrm{a}}$ & .818 & .805 & .68767 \\
\hline
\end{tabular}

\section{Sumber : Hasil Pengolahan Data, 2019}

Berdasarkan tabel di atas diperoleh nilai adjusted $R$ Square $\left(\mathrm{R}^{2}\right)$ koefisien determinasi sebesar 0,805 atau sama dengan $80,5 \%$ dipengaruhi oleh variabel independen terhadap variabel dependen sedangkan sisanya 19,5\% dipengaruhi variabel lain seperti seperti inflasi, suku bunga dan arus kas.

\section{Pengujian hipotesis secara simultan (Uji F) Tabel 9. Uji F ANOVA $^{a}$}

\begin{tabular}{|c|c|c|c|c|c|c|}
\hline Model & & $\begin{array}{l}\text { Sum of } \\
\text { Squares }\end{array}$ & df & Mean Square & $\mathrm{F}$ & Sig. \\
\hline \multirow[t]{3}{*}{1} & Regression & 91.288 & 3 & 30.429 & 64.348 & $.000^{b}$ \\
\hline & Residual & 20.334 & 43 & .473 & & \\
\hline & Total & 111.623 & 46 & & & \\
\hline
\end{tabular}

\section{Sumber : Hasil Pengolahan Data, 2019}

Pada Tabel 9 dapat dilihat bahwa Uji signifikasi simultan / bersama - sama (uji statistic $F)$ menghasilkan nilai $F_{\text {hitung }}$ adalah sebesar 64,348dengan nilai signifikan 0,000 , sedangkan $F_{\text {tabel }}(54-4=50)$ adalah sebesar 2,79 maka kesimpulannya adalah $\mathrm{F}_{\text {hitung }}>\mathrm{F}_{\text {tabel }}$ yaitu 64,348 > 2,79 sehingga keputusannya adalah Ho ditolak dan Ha diterima, artinya variabel Laba Per Saham, Rasio Hutang dan Pengembalian Atas Aset (ROA) berpengaruh dan signifikan Terhadap Harga Saham Pada Perusahaan Pertambangan yang Terdaftar di Bursa Efek Indonesia Periode 2012-2017.

\section{Pengujian hipotesis secara parsial (Uji T) Tabel 10. Uji T}

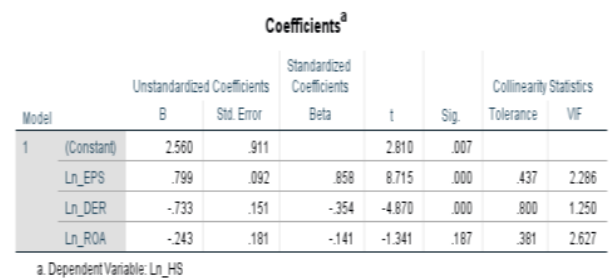

Sumber : Hasil Pengolahan Data, 2019

Pada tabel 10 dapat dilihat bahwa Laba Per Saham mempunyai nilai $t_{\text {hitung }}$ adalah sebesar 8,715 dengan nilai signifikan $0,000<0,05$, sedangkan nilai $t_{\text {tabel }}(54-4=50)$ adalah sebesar 2,008 sehingga kesimpulannya adalah $\mathrm{t}_{\text {hitung }}$ $>t_{\text {tabel }}$ yaitu $8,715>2,008$, artinya variabel laba per saham berpengaruh dan signifikan terhadap harga saham. Rasio hutang mempunyai nilai $t_{\text {hi- }}$ tung $-4,870$ dengan nilai signifikan $0,000<0,05$, sedangkan $t_{\text {tabel }}$ adalah sebesar 2,008 maka kesimpulannya adalah $-\mathrm{t}_{\text {hitung }}<-\mathrm{t}_{\text {tabel }}$ yaitu $-4,870<-$ 2,008, artinya variabel Rasio Hutang tidak berpengaruh dan signifikan terhadap harga saham. Pengembalian Atas Aset (ROA) mempunyai nilai $t_{\text {hitung }}-1,341$ dengan nilai signifikan 0,187> 0,05 , sedangkan $t_{\text {tabel }}$ adalah sebesar 2,008 maka kesimpulannya adalah $-\mathrm{t}_{\text {hitung }}<-\mathrm{t}_{\text {tabel }}$ yaitu $1,341<-2,008$, artinya variabel Pengembalian Atas Aset (ROA) berpengaruh dan tidak signifikan terhadap harga saham. 
Pengaruh Laba Per Saham Terhadap Harga Saham

Hasil perhitungan diperoleh nilai t hitung $>\mathrm{t}$ tabel atau 8,715 >2,008 maka Ho ditolak dan $\mathrm{H}_{\mathrm{a}}$ diterima artinya laba per saham berpengaruh positif dan signifikan terhadap harga saham pada perusahan pertambangan yang terdaftar di Bursa Efek Indonesia periode 2012-2017.

Berdasarkan hasil penelitian di atas, menunjukkan bahwa ketika Laba Per Saham tinggi maka harga saham akan ikut tinggi, sedangkan ketika laba per saham rendah maka harga saham juga akan rendah.

Hasil penelitian ini sejalan dengan hasil hipotesis Yuliani dan Supriadi (2014). Penelitian ini juga sejalan dengan Ryan,Atmadja dan Adiputra (2014) yang mengemukakan bahwa EPS memiliki pengaruh terhadap Harga Saham. Hasil penelitian ini juga sejalan dengan penelitian yang dilakukan Rufipurwanti (2016) yang menyatakan, EarningPer Share (EPS) secara parsial berpengaruh signifikan terhadap harga saham.

Hasil dari penelitian ini sejalan dengan teori Kodrat dan Indonanjaya (2010:283) hubungan antara harga saham seharusnya dengan Earning Per Share (EPS) adalah positif, yaitu semakin besar pendapatan per lembar saham, semakin besar harga dari saham.

\section{Pengaruh Rasio Hutang Terhadap Harga Sa- ham}

Hasil perhitungan diperoleh nilai -t hitung $<-t$ tabel atau $-4.870<-2,008$ maka Ho diterima Ha ditolak artinya rasio hutang tidak berpengaruh dan signifikan terhadap harga saham pada perusahaan pertambangan yang terdaftar di Bursa Efek Indonesia periode 2012-2017.

Berdasarkan hasil penelitian di atas, menunjukkan bahwa ketika Debt To Equity Ratio mengalami kenaikan maka harga saham belum tentu akan mengalami kenaikan juga. Rasio ini dihitung sebagai hasil bagi antara total utang dengan modal. Rasio ini berguna untuk mengetahui besarnya perbandingan antara jumlah dana yang berasal dari pemilik perusahaan dan memberikan petunjuk umum tentang kelayakan kredit dan risiko keuangan debitor. Alipudin dan Oktaviani (2016)
Hasil penelitian ini juga sejalan dengan Alipudin dan Oktaviani (2016) yang menyatakan bahwa DER tidak berpengaruh terhadap harga saham.

Hasil penelitian ini tidak sejalan dengan penelitian yang dilakukan Dewi dan Suaryana (2013) yang menyatakan DER berpengaruh negatif signifikan terhadap harga saham.

Hasil penelitian ini juga tidak sejalan dengan teori Kodrat dan Indonanjaya (2010:283) , hubungan antara harga saham seharusnya dengan Debt to Equity Ratio (DER) adalah positif, yaitu semakin besar rasio antara utang dengan modal, semakin besar harga dari saham.

\section{Pengaruh Pengembalian Atas Asset(ROA) Terhadap Harga Saham}

Hasil perhitungan diperoleh nilai -t hitung $<-$ t tabel atau -1,341 <-2,008 maka Ha ditolak Ho diterima artinya pengembalian atas aset (ROA) tidak berpengaruh dan tidak signifikan terhadap harga saham pada perusahaan pertambangan yang terdaftar yang terdaftar di Bursa Efek Indonesia periode 2012-2017.

Berdasarkan hasil penelitian di atas, menunjukkan bahwa kenaikan pada ROA tidak selalu diikuti kenaikan pada harga saham. Hal ini dapat diakibatkan para investor dalam memperhatikan harga saham tidak hanya dilihat dari segi internal perusahaan seperti total aset, tetapi juga melihat dari segi eksternal perusahaan dan kondisi pasar seperti kenaikan inflasi, perubahan kebijakan ekonomi dan politik dari pemerintah. Permintaan dan penawaran harga saham dalam pasar modal berpengaruh dalam keputusan investasi yang menyebabkan fluktuasi harga saham. Hasil penelitian ini sejalan dengan G.E.Y.Egam, V.Ilat, S.Pangerapan (2017) yang menyatakan bahwa ROA tidak berpengaruh terhadap naik turunnya harga saham.

Hasil penelitian ini tidak sejalan dengan teori Kodrat dan Indonanjaya (2010:282) hubungan antara haraga saham seharusnya dengan Return On Asset (ROA) adalah positif, yaitu semakin besar hasil yan diperoleh dari aset, semakin besar harga dari saham.

Hasil penelitian ini juga tidak sejalan dengan penelitian yang dilakukan Rufipurwanti (2016) yang menyatakan Return On Asset berpengaruh signifikan terhadap harga saham. 


\section{KESIMPULAN}

Berdasarkan penelitian yang telah dilakukan, maka dapat disimpulkan bahwa :

1. Laba per Saham, Rasio Hutang dan Pengembalian Atas Aset (ROA) berpengaruh secara simultan terhadap Harga Saham pada Perusahaan Pertambangan yang terdaftar di Bursa Efek Indonesia Periode 2012-2017.

2. Laba per Saham secara parsial berpengaruh dan signifikan terhadap Harga Saham, Rasio Hutang secara parsial tidak berpengaruh dan signifikan terhadap Harga Saham, dan Pengembalian Atas Asset (ROA) secara parsial tidak berpengaruh dan tidak signifikan terhadap Harga Saham para Perusahaan Pertambangan yang terdaftar di Bursa Efek Indonesia Peri-

\section{SARAN} ode 2012-2017.

Berdasarkan hasil penelitian pada bab sebelumnya, maka penulis memberikan saran untuk Penelitian selanjutnya sebagai berikut:

Bagi perusahaan pertambangan disarankan sebaiknya mengendalikan hutang dengan baik, agar mampu meningkatkan harga saham perusahaan dan pihak manajemen selalu membagikan laba per lembar saham agar investor tertarik melakukan investasi di perusahaan.

Bagi pihak investor disarankan sebaiknya hasil penelitian ini dapat dijadikan sebagai bahan pertimbangan bagi para investor untuk mengetahui tingkat harga saham yang ada di pasar modal.

\section{DAFTAR RUJUKAN}

Alipudin, Asep dan Oktaviani, Resi. 2016.Pengaruh EPS,ROE,ROA dan DER terhadap Harga Saham pada Perusahaan Sub Sektor Semen yang Terdaftar di BEI. Jurnal Ilmiah Akuntansi Fakultas Ekonomi Vol.2 No.1 E-ISSN 2502-4159

Buchari, Sitti. 2015. Pengaruh ROA,ROE, dan EPS terhadap Harga Saham PT.Unilever Indonesia Tbk Periode 2007-2014
Dewi, Dina Putu Aristya dan Suaryana. 2013. Pengaruh EPS, DER, Dan PBV Terhadap Harga Saham. Jurnal Akuntansi Universitas Udayana 4.1. ISSN 23028556

G.E.Y.Egam,V.Ilat,S.Pangerapan.2017. Pengaruh ROA,ROE,NPM,EPS terhadap Harga Saham Perusahaan Yang Tergabung dalam Indeks LQ45 di Bursa Efek Indonesia Periode Tahun 20122015. Jurnal EMBA Vol.5 No.1 ISSN 2303-1174.

Hanafi, Mamduh dan Halim, Abdul. 2014. Analisis Laporan Keuangan. Edisi Keempat. Yogyakarta. Penerbit UPP STIM YKPN

Hery. 2016. Analisis Laporan Keuangan

Integrated And Comprehen

sive Edition. Jakarta : PT

Gramedia

Kodrat, David Sukardi \& Kurniawan In donanjaya. 2010. Manajemen

Investasi : Pendekatan

Teknikal dan Fundamental untuk Analisis Saham. Yogya

karta : Graha Ilmu

Murhadi, Wener. 2013 : Analisis Laporan

Keuangan Proyeksi dan Val

uasi Saham.Jakarta : Penerbit

Salemba Empat

Prastowo, Dwi. 2015. Analisis Laporan

Keuangan Konsep dan Aplikasi. Edisi

Ketiga.Cetakan Ketiga. Yogyakarta :

Unit Penerbit dan Percetakan Sekolah

Tinggi Ilmu Manajekemn YKPN

Widioatmodjo, Sawidji. 2012. Cara Sehat

Investasi di Pasar Modal.

Edisi Revisi. Jakarta : PT.Elex

Media Komputindo

Rufipurwanti. 2017. Pengaruh Return On

Assets, Return on Equity, Debt

to Equity Ratio dan Earning

Per Share Terhadap Harga

Saham Pada Perusahaan Sub

Sektor Food And Beveraes

Yang Terdaftar Di Bursa Efek 
Indonesia (BEI) Tahun 2012-

2015. Jurnal Sekolah TInggi

Keguruan dan Ilmu Pendidi

kan (STKIP) PGRI

Putu Ryan Damayanti, Anantawikrama Tungga Atmadja, Made Pradana Adiputra. 2014. Pengaruh Dividend Per Share dan Earning Per Share terhadap Harga Saham Pada Perusahaan Industri Barang Konsumsi Yang Terdaftar di Bursa Efek Indonesia Periode 2010-2012. Jurnal Akuntasi Program S1 Vol.2 No.1

Yuliani dan Supriadi. 2014. Pengaruh Earning Per Share dan Dividend Per Share Terhadap Harga Saham Perusahaan Yang Go Public. Jurnal Ilmiah Manajemen Kesatuan, Vol.2 No.2, 2014 pp.111-118 STIE Kesatuan ISSN 2337-7860. 